\title{
Rofecoxib heeft een beschermend effect op het ontstaan van colorectale adenomen, maar tegen welke prijs?
}

\author{
A. Vermes
}

Uit verschillende onderzoeken is gebleken dat niet-steroïde anti-inflammatoire middelen (NSAID's) gerelateerd zijn aan een verminderd risico op oncologische aandoeningen van het colon en rectum. Ondanks het feit dat de onderliggende werkingsmechanismen onbekend zijn, wordt algemeen gedacht dat de remming van het enzym cyclo-oxygenase (COX), in het bijzonder de variant COX2 , een essentiële rol hierbij speelt. In een recent gerandomiseerd, placebogecontroleerd, dubbelblind onderzoek is nagegaan in hoeverre de selectieve COX-2-remmer rofecoxib in staat is tot het verminderen van het risico op colorectale adenomen.

In totaal werden 2587 patiënten met een recent verleden van histologisch bevestigde adenomen gerandomiseerd voor een dagelijkse behandeling met rofecoxib of placebo. Evaluatie van alle patiënten, onder meer door middel van colonoscopie, gebeurde één en drie jaar na starten van de behandeling. Het primaire eindpunt van het onderzoek betrof het voorkomen van gediagnosticeerde adenomen gedurende drie jaar behandeling met rofecoxib of placebo. Uit de resultaten blijkt dat adenomen minder frequent optraden bij patiënten die werden behandeld met rofecoxib in vergelijking tot placebo ( $41 \%$ versus $55 \%, \mathrm{p}<0,0001$, risicoreductie 0,76 ). Eveneens was een gunstig effect waarneembaar op vergevorderde adenomen ( $\mathrm{p}<0,01$, rofecoxib versus placebo). Het chemoprotectieve effect was het meest uitgesproken gedurende het eerste jaar van behandeling. Naast deze gunstige effecten ondervonden de met rofecoxib behandelde patiënten significant meer ernstige bijwerkingen: ernstige trombotische, cardiovasculaire bijwerkingen $(3,7 \%$ versus $2,1 \%, p=0,008)$ en ernstige gastrointestinale bijwerkingen $(2,1 \%$ versus $0,46 \%, \mathrm{p}<0,001)$.

In zowel de conclusie van de onderzoekers als ook het redactionele commentaar behorend bij het onderzoek wordt benadrukt dat sprake is van een chemoprotectief effect van rofecoxib op het ontwikkelen van colorectale adenomen, maar dat dit echter tegen een (te?) hoge prijs gebeurt, gezien het verhoogde optreden van onder meer ernstige, trombotische cardiovasculaire bijwerkingen. Hiermee lijkt het op grote schaal inzetten van NSAID's als chemoprotectivum zo goed als uitgesloten.

\section{Literatuur}

Rofecoxib: in Nederland vroeger verkrijgbaar als Vioxx ${ }^{\circledR}$

\section{Literatuur}

Baron JA, Sandler RS, Bresalier RS, Quan H, Riddell R, Lanas A, et al. A randomized trial of rofecoxib for the chemoprevention of colorectal adenomas. Gastroenterology 2006; 131: 1674-82.

Lynch PM. Is the demonstration of adenoma reduction with rofecoxb a pyrrhic victory? Gastroenterology 2006; 131: 2003-5. 